\title{
Effect of Temperature on Apothecial Longevity and Ascospore Discharge by Apothecia of Monilinia vaccinii-corymbosi
}

\author{
Phillip S. Wharton and Annemiek C. Schilder, Department of Plant Pathology, Michigan State University, East \\ Lansing 48824
}

\begin{abstract}
Wharton, P. S., and Schilder, A. M. C. 2005. Effect of temperature on apothecial longevity and ascospore discharge by apothecia of Monilinia vaccinii-corymbosi. Plant Dis. 89:397-403.

Pseudosclerotia of Monilinia vaccinii-corymbosi with apothecial initials were collected from blueberry (Vaccinium corymbosi cv. Jersey) fields in Grand Junction, MI, in the spring of 2002 and 2003 and monitored during apothecial development and maturation. Apothecia with cup openings as small as $1.2 \mathrm{~mm}$ in diameter were able to discharge ascospores. The number of ascospores discharged increased exponentially as the diameter of the cup opening increased, before leveling off at a cup diameter of about $6 \mathrm{~mm}$. Cytological studies showed that ascospore discharge correlated well with the stage of development of asci and ascospores in the apothecium. The effect of temperature on the longevity of apothecia was studied at 10, 15, 20, and $25^{\circ} \mathrm{C}$. Initial ascospore discharge was greater for apothecia incubated at higher temperatures (20 and $25^{\circ} \mathrm{C}$ ). However, total discharge was greater in apothecia incubated at lower temperatures $\left(10\right.$ and $15^{\circ} \mathrm{C}$ ), as they persisted longer than those incubated at 20 and $25^{\circ} \mathrm{C}$. Incubating apothecia at freezing temperatures $\left(-2,-4,-6\right.$, and $\left.-8^{\circ} \mathrm{C}\right)$ for $1 \mathrm{~h}$ resulted in a 50 to $98 \%$ reduction in the number of ascospores discharged compared with before freezing. However, apothecia incubated down to $-6^{\circ} \mathrm{C}$ were able to recover their ability to discharge ascospores by 2 days after the freezing treatment. Ascospores discharged from apothecia after freezing at $-2^{\circ} \mathrm{C}$ for $1 \mathrm{~h}$ remained viable. However, the germination ability of ascospores from apothecia frozen at $-4,-6$, and $-8^{\circ} \mathrm{C}$ decreased with decreasing temperature such that only $10 \%$ of ascospores from apothecia frozen at $-8^{\circ} \mathrm{C}$ germinated successfully. The information obtained in this study may be useful in the development of scouting and management strategies for the control of mummy berry disease.
\end{abstract}

Additional keywords: carpogenic germination, disease prediction, freezing tolerance in fungi

Mummy berry disease of Vaccinium spp., caused by Monilinia vaccinii-corymbosi (Reade) Honey, is a major problem throughout blueberry growing regions of the United States and Canada (1,7). The principal damage on highbush blueberry $(V$. corymbosum L.) is the blighting of young shoots and flowers, caused by ascosporic infections (7). Blighting of flower clusters alone may result in up to $80 \%$ reduction in crop yield (3). Losses due to blighting of shoots (shoot strikes) are more difficult to define, as they affect next year's fruit production. The secondary phase of the disease, conidial infection of the flower and ovaries, resulting in mummification of fruit, further reduces yields (7). In addition, there is a zero tolerance for mummified berries in processed fruit $(4,19)$.

The life cycle of $M$. vaccinii-corymbosi has three major components: (i) a fallwinter dormant phase, (ii) an early-spring

\section{Corresponding author: Phillip S. Wharton \\ E-mail: whartonp@msu.edu}

Accepted for publication 15 November 2004.

DOI: 10.1094/PD-89-0397

(C) 2005 The American Phytopathological Society primary infection phase, and (iii) a latespring secondary infection phase (1). The fungus overwinters as pseudosclerotia on the ground below blueberry bushes. Apothecia develop from the pseudosclerotia in early spring when the temperature rises above $7^{\circ} \mathrm{C}$ (1). Primary infection of blueberry bushes occurs when ascospores are forcibly ejected from apothecia and infect young vegetative and flower-bud tissues, causing a blight of the newly emerging growth (11). Secondary infection occurs when conidia produced on blighted tissue are carried by wind and pollinating insects to flower stigmas, where they germinate and grow down the style into the ovary (14). The fungus then colonizes the fruit tissues interand intracellularly, producing no visible external symptoms until the fruit starts to ripen, at which point infected berries turn pink or light brown, begin to dry up (mummify), and drop to the ground (7).

The phenologies of $M$. vacciniicorymbosi and its blueberry host are highly coordinated (11). In this pathosystem, the host and pathogen show defined periods of susceptibility and infectivity, respectively, during initiation of disease in the spring $(1,2,10,15)$. Primary infection can occur only when ascospores are produced and disseminated during the period of host susceptibility, which corresponds to bud break and shoot elongation in blueberry $(6,16)$. Such susceptible tissue is present only for a relatively short time, so pathogen development must be synchronized with that of the host in order for disease to occur.

In order to germinate, pseudosclerotia require a cold period of at least 900 to 1,200 chill hours (the number of hours with temperatures between 0 and $7^{\circ} \mathrm{C}$; 11,13,20). This range is similar to that required for adequate bud break in highbush blueberry and allows apothecial development to coincide with early blueberry shoot development (11). Thus, by understanding the environmental factors that may affect the development and longevity of apothecia, and their ability to discharge ascospores, it may be possible to develop control strategies based on disease avoidance or to refine the timing of fungicide applications in disease control programs.

Several studies have explored the effects of environmental parameters on discharge of ascospores of $M$. vaccinii-corymbosi (15-17). Ramsdell et al. (16) studied the pattern of ascospore release of $M$. vacciniicorymbosi in field plots. They reported that there was a strong inverse relationship between relative humidity and ascospore discharge, with ascospores being discharged in a circadian-like rhythm (15). In 1973, ascospores were detected in the air from 3 April (before bud break) to 8 May (prebloom). A peak in ascospore release occurred on 19 April that year and corresponded roughly to the quantity of apothecia present below the bushes (16). Information on inoculum availability in relation to plant development was then used to refine the timing and choice of materials for fungicide applications to reduce primary infection (15-17).

No studies have directly investigated the effects of environmental parameters on apothecial longevity and ascospore discharge. However, studies carried out by Lehman and Oudemans (11) and Cox and Scherm (5) showed that apothecia can survive for up to 30 days at between 6 and $8^{\circ} \mathrm{C}$ and 16 days at $15^{\circ} \mathrm{C}$. Studies on Monilinia fructicola (G. Wint.) Honey have also shown that temperature has an effect on the longevity of apothecia and ascospore discharge, with apothecia incubated at 10 and $15^{\circ} \mathrm{C}$ surviving longer than those incubated at 20 and $25^{\circ} \mathrm{C}(8)$. 
In southwest Michigan, apothecia are normally first observed in the field around the end of March or the beginning of April. At this time of year, the temperatures can range from a daytime high of $32^{\circ} \mathrm{C}$ to a nighttime low of $-8^{\circ} \mathrm{C}$, with average day and night temperatures of 14 and $2{ }^{\circ} \mathrm{C}$, respectively (12). As such, apothecia can be subjected to an extreme range of temperatures. It is important to understand how such extreme changes in temperature affect the longevity of apothecia and discharge of ascospores. If high daytime temperatures decrease the longevity of apothecia in $M$. vaccinii-corymbosi as is the case with $M$. fructicola, then this may reduce the number of fungicide applications necessary to control primary infections. Field observations also indicated that apothecia may be damaged by freezing temperatures, as apothecia collected after heavy frosts appeared desiccated, cracked, and discolored. Furthermore, they did not discharge ascospores when they were incubated at $15^{\circ} \mathrm{C}$ (P. S. Wharton and A. M. C. Schilder, unpublished data).

An understanding of the environmental factors that affect the maturation and longevity of apothecia and their ability to discharge ascospores is important for the development of control strategies based on disease avoidance. However, in order to gain an insight into what factors affect development of apothecia, it is first necessary to have an understanding of the anatomical and morphological processes involved in their development. A knowledge of when apothecia are mature enough to discharge ascospores would also be of practical benefit, as it would facilitate disease control decision-making based on field scouting for apothecia at these stages of development. Thus, the objectives of this study were: (i) to investigate the relationship between apothecial maturation and the quantity of ascospores released, (ii) to determine the effects of temperature on the longevity of apothecia and ascospore discharge, and (iii) to determine the effect of freezing of apothecia on subsequent ascospore discharge and viability.

\section{MATERIALS AND METHODS}

Collection of pseudosclerotia. Pseudosclerotia with apothecial initials 1 to $2 \mathrm{~mm}$ in length were collected from blueberry (cv. Jersey) fields in Grand Junction, MI, at the end of March in 2002 and 2003. Pseudosclerotia were incubated on a 1-cmdeep layer of moist sand in 3.8-liter Sterilite containers (Sterilite Corporation, Townsend, MA), with the tops of the containers covered with plastic wrap to maintain relative humidity above $95 \%$. Containers were then incubated in an environmental chamber under fluorescent lights in a 12 -h photoperiod at $15^{\circ} \mathrm{C}$ to initiate apothecial development.

Development of apothecia and maturation of ascospores. Ten pseudosclerotia with apothecial initials were placed on sandy soil in a plastic container as described above. When the apothecial stipes started to swell and produce cups, they were surrounded by a clear plastic cylinder (20 mm diameter) on top of which a petri dish base $(3.5 \times 1 \mathrm{~cm})$ was placed so that ascospores were discharged onto the petri dish. The lids were removed daily and rinsed with $2 \mathrm{ml}$ of sterile deionized water (SDW) containing $0.01 \%$ Tween 20. The surface of the lid was then gently rubbed with an ethanol-sterilized pipette bulb to dislodge ascospores. The resulting suspension was decanted into a glass vial, and one drop of iodine solution was added. Vials were stored in a refrigerator for counting at a later date. The diameter of the apothecial cup opening was measured daily in two perpendicular directions, and the apothecia were photographed from above to document their stage of development. Each individual apothecium was monitored until no more ascospores were discharged. The ascospores in the suspension were counted using a hemacytometer. Data on cup size versus ascospore discharge were analyzed, and regression equations and plots were produced using SigmaPlot 2000 (Systat Software Inc., Richmond, CA).

In a parallel experiment, five apothecia, each with a cup diameter opening of 1,5 , or $11 \mathrm{~mm}$, were removed from their pseudosclerotia and fixed in FAA $3.5 \%$ formaldehyde, $5 \%$ glacial acetic acid, and $47 \%$ ethanol in deionized water). Hand sections through the apothecia were then made, and the stage of development of the asci and ascospores was documented photographically using an Olympus BX40 research microscope with a Nikon Coolpix 990 digital camera (Nikon Inc., Melville, NY). All experiments were carried out twice, once in 2002 and once in 2003.

Effect of temperature on longevity of apothecia. Pseudosclerotia containing apothecia with fully formed cups that were just starting to open were transferred to petri dishes $(15 \times 2 \mathrm{~cm})$ and secured to the base of the dish with Vaseline. The dishes were then inverted over the base of another petri dish containing $15 \mathrm{ml}$ of SDW and $0.01 \%$ Tween 20, and sealed with Parafilm. In 2002, up to six pseudosclerotia were used per dish depending on the number of apothecia per pseudosclerotium, so that the total number of apothecia per dish was at least 12. In 2003, due to fewer pseudosclerotia being available for experiments, at least three pseudosclerotia were used so that the total number of apothecia per dish was at least six. All apothecia used had cups of a similar size (8 to 10 $\mathrm{mm}$ diameter). Three dishes were incubated in the dark for each temperature treatment $\left(10,15,20\right.$, and $\left.25^{\circ} \mathrm{C}\right)$. Apothecia were allowed to discharge ascospores overnight into SDW. The water was then decanted into a 20-ml scintillation vial.
Five drops of an iodine solution containing $6.68 \%$ iodate were added to the vial, which was stored in a refrigerator for counting at a later date. The lids were then replaced with fresh sterile lids and SDW. In 2002, the pseudosclerotia were incubated for 7 days. However, it was noted that apothecia incubated at 10 and $15^{\circ} \mathrm{C}$ had senesced by this time, so in 2003 the experiment was carried out until all apothecia had senesced. Senescence of apothecia was accompanied by a loss of structural integrity and collapse of the apothecial cup. The number of ascospores discharged daily per dish was quantified using a hemacytometer. Four counts were taken for each plate and averaged to give the total number of ascospores per dish. The experiment was carried out in 2002 and repeated in 2003. Statistical analyses were carried out using a repeated measures design and the mixed model (Proc Mixed) procedure in the SAS statistical analysis software (SAS Institute, Cary, NC), and treatment means were separated using the least squares means test. Data from the experiment carried out in 2002 were analyzed separately from those carried out in 2003.

Effect of freezing on ascospore discharge and viability. Pseudosclerotia containing apothecia with fully formed cups ( 8 to $10 \mathrm{~mm}$ diameter) were placed in petri dishes $(15 \times 2 \mathrm{~cm})$ and incubated at $15^{\circ} \mathrm{C}$ for $24 \mathrm{~h}$ as described above. Petri dishes (two per temperature) were then prechilled to $4^{\circ} \mathrm{C}$ for $1 \mathrm{~h}$ (6) before being incubated at $-2,-4,-6$, or $-8^{\circ} \mathrm{C}$ for $1 \mathrm{~h}$ in Peltier effect temperature-controlled chambers (Sable Systems, Inc., Las Vegas, $\mathrm{NV}$ ). After the cold treatment, dishes were incubated at $15^{\circ} \mathrm{C}$ and ascospores collected as described above. The lids were replaced daily for 2 days, and any spores discharged were collected and counted with a hemacytometer as described above. The number of ascospores discharged after freezing was compared with the number discharged before freezing.

In a parallel experiment, apothecia that had been incubated at the same temperatures as above were incubated at $15^{\circ} \mathrm{C}$ and allowed to discharge spores onto $0.45-\mu \mathrm{m}$ Millipore filters instead of into SDW. Three petri dishes were used per temperature with three pseudosclerotia per plate. Three filters were placed in each petri dish, one underneath each pseudosclerotium. After $24 \mathrm{~h}$, the filters were placed in sterile $15-\mathrm{ml}$ centrifuge tubes and rinsed with 1 $\mathrm{ml}$ of SDW by vortexing the tubes for 3 min. The resulting spore suspensions were then plated out on potato dextrose agar (PDA) and incubated overnight at $25^{\circ} \mathrm{C}$. Spore viability was determined by assessing the percent germination of ascospores with the aid of a dissecting microscope at $\times 100$ magnification. Ascospores were considered to have germinated if the germ tube was longer than the diameter of the ascospore. For each plate, the number of 
germinated ascospores and the total number of ascospores in three separate fields of view were counted. The percentage of germinated ascospores for each field of view was then calculated and the numbers averaged to give percentage of germinated ascospores per plate. All experiments were carried out twice in 2003. Statistical analysis of ascospore discharge was conducted using a repeated measures design as described above, and analysis of ascospore viability was carried out using the general linear model (GLM) procedure in the SAS statistical analysis software (SAS Institute). Treatment means were separated with Fisher's protected LSD $(\alpha=0.05)$ test.

\section{RESULTS}

Development of apothecia and maturation of ascospores. After approximately 1 week at $15^{\circ} \mathrm{C}$, the tips of the apothecial stipes started to swell and develop into cup-shaped structures, giving the apothecium the appearance of a miniature goblet (Fig. 1A). In general, apothecia started to discharge ascospores when the opening in the cup reached $2 \mathrm{~mm}$ in diameter (Fig. 2). However, ascospores were discharged by some apothecia with cup diameters as small as $1.2 \mathrm{~mm}$. The number of ascospores discharged per day increased exponentially as the diameter of the cup opening increased, before leveling off at a diameter of about $7 \mathrm{~mm}$ in 2002 and $5 \mathrm{~mm}$ in 2003 (Fig. 2).

Examination of hand sections of apothecia revealed that they consisted of three layers, the hymenium, the hypothecium, and the excipulum, as described previously for fungi in the discomycetes $(9,13)$. In apothecial cups with openings of $1 \mathrm{~mm}$ diameter, the hymenium consisted mainly of paraphyses, while the hypothecium consisted of two parts, a dark layer (DL) of densely packed hyphae and a lighter layer (LL) of more loosely woven hyphae (Fig. 3A). Closer examination of the hymenium revealed the presence of asci at various stages of development, from immature to immature but fully expanded, to mature with fully formed ascospores. Asci developed from hyphae in the hypothecium and grew up between the paraphyses (Figs. 3B and C). In apothecial cups with 5-mmdiameter openings, the hymenium con- sisted mainly of mature asci, and the hypothecium of two layers (dark and light) of similar thickness (Fig. 3D). At high magnification, eight mature ascospores were clearly visible in most of the asci, and paraphyses could be seen jutting out

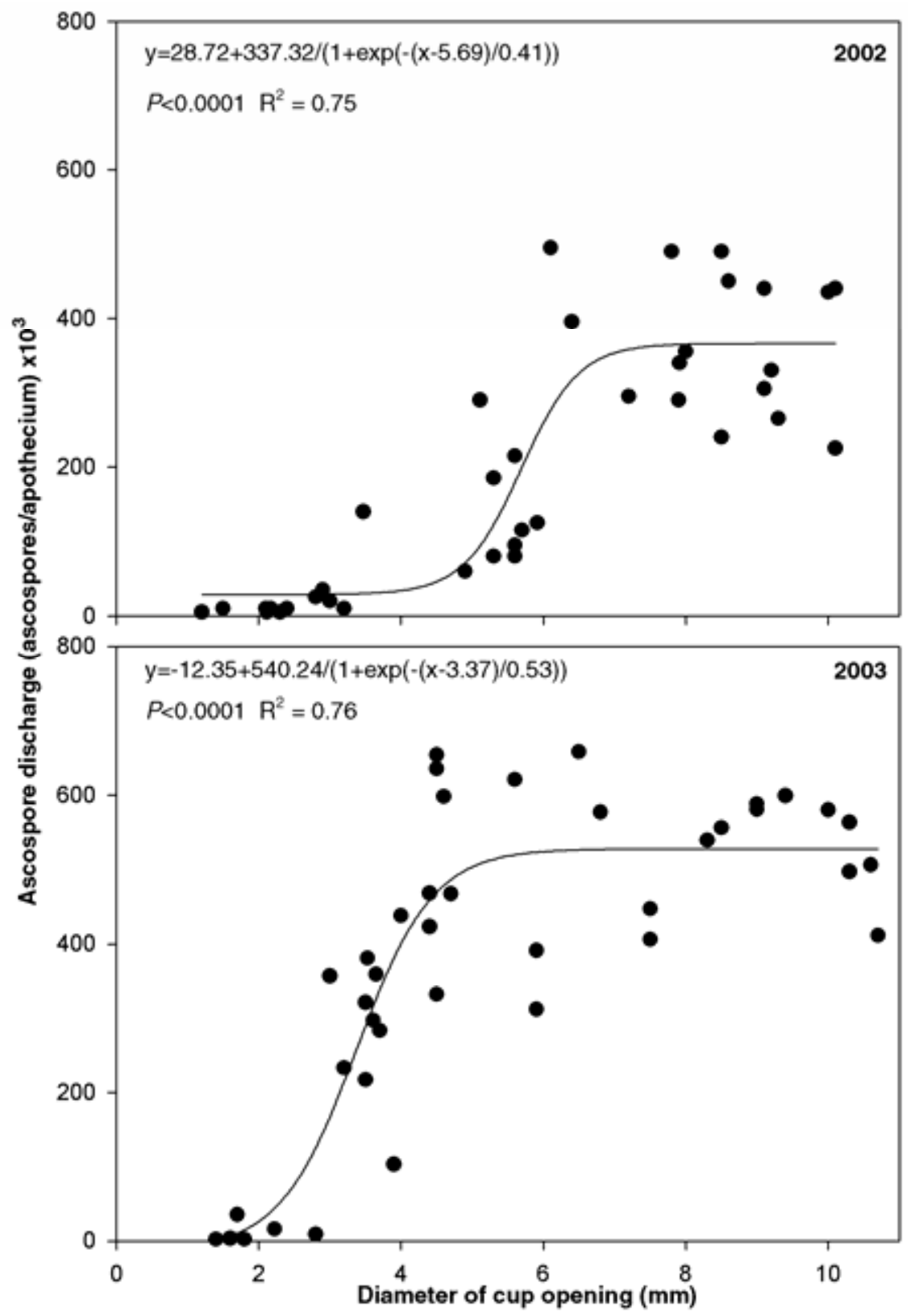

Fig. 2. Relationship between apothecium cup size and total number of ascospores discharged per day by apothecia of Monilinia vaccinii-corymbosi in experiments carried out in 2002 and 2003. among the asci (Fig. 3E). The structure of apothecia with cup openings of $11 \mathrm{~mm}$ diameter was very similar to that of apothecia with cup openings of $5 \mathrm{~mm}$ diameter (Fig. 3F). However, the hymenium appeared more disorganized (Fig. 3F and G), and the 


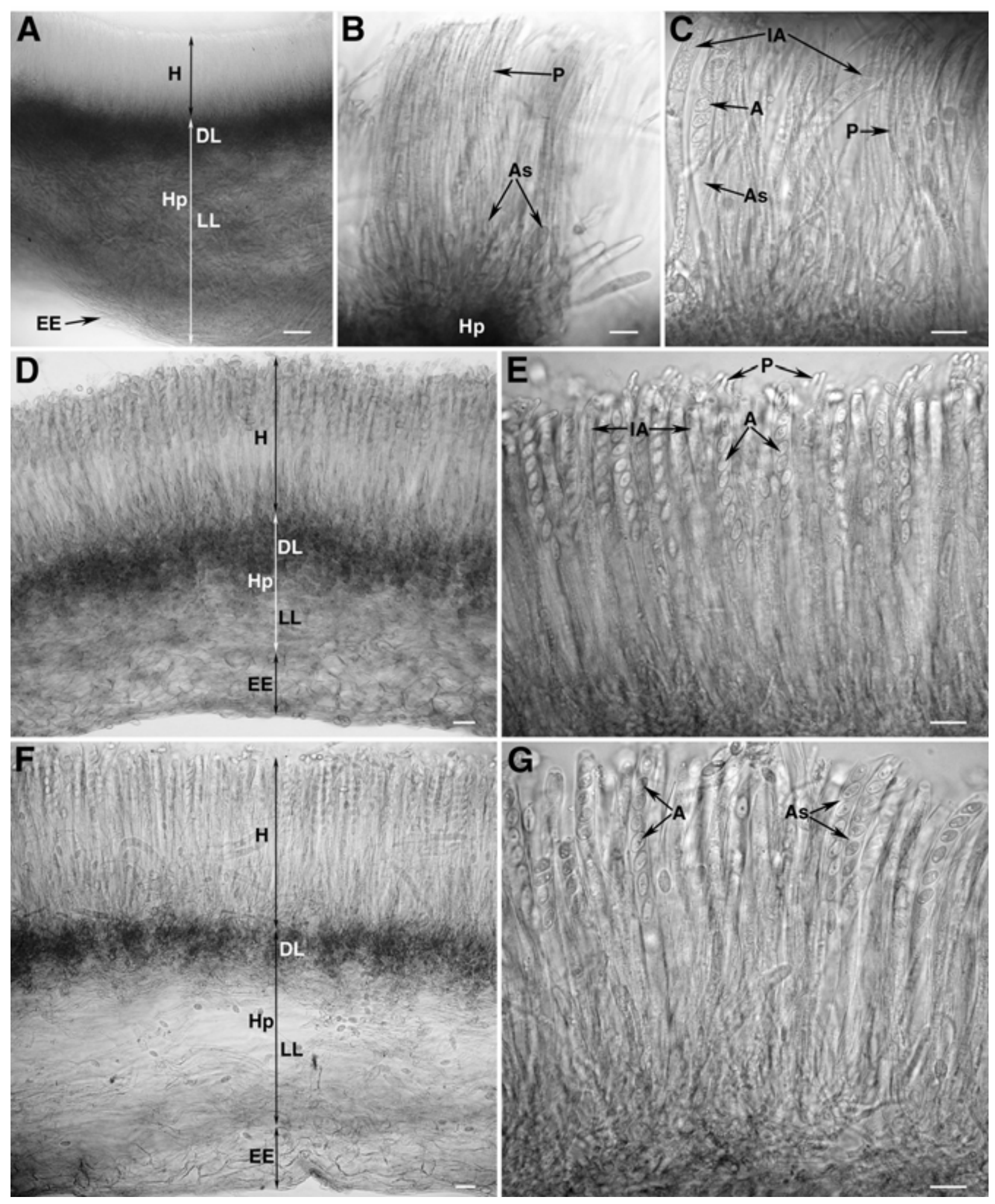

Fig. 3. Light micrographs of hand sections through Monilinia vaccinii-corymbosi apothecia. A, Cross section through immature apothecium with cup opening $1 \mathrm{~mm}$ diameter. Note that the hymenium $(\mathrm{H})$ consists mainly of paraphyses. The hypothecium $(\mathrm{Hp})$ consists of two parts, a dark layer (DL) of densely packed hyphae and a lighter layer (LL) of loosely packed hyphae. A small area of the ectal excipulum (EE) is just visible at bottom left. Bar $=50 \mu \mathrm{m}$. B, C, High-magnification light micrographs of squashed cross section shown in (A). B, Young asci (As) develop from the dark layer of hypothecium and grow up between the paraphyses (P). Bar $=20 \mu \mathrm{m}$. C, Asci at various stages of development, from immature but fully grown (IA), to mature (As) with fully formed ascospores (A) visible interspersed among paraphyses. Bar $=20 \mu \mathrm{m}$. D, Cross section of mature apothecium with cup opening $5 \mathrm{~mm}$ diameter. Hymenium now consists mainly of mature asci. The two layers of hypothecium, dark layer and light layer, are of approximately the same thickness. Ectal excipulum is also visible beneath hypothecium. Bar $=25 \mu \mathrm{m}$. E, High-magnification light micrograph of hymenium shown in (D). Eight mature ascospores are visible in most asci. Some immature asci and paraphyses can also be seen interspersed among asci. Bar $=20 \mu \mathrm{m}$. F, Cross section of mature apothecium with cup opening $11 \mathrm{~mm}$ diameter. Hymenium appears more disorganized than that shown in (D). Dark layer of hypothecium appears less dense and thinner, and light layer appears wider and less dense than in (D). Bar $=25 \mu \mathrm{m}$. G, High magnification of hymenium shown in (F). Asci appear more disorganized and less tightly packed than in (E). Few paraphyses and immature asci are visible interspersed among the asci. Bar $=20 \mu \mathrm{m}$. 
light layer in the hypothecium was much wider and less dense than that of 5-mmdiameter cups (Fig. 3F).

Effect of temperature on longevity of apothecia. Experiments carried out in 2002 and 2003 showed that apothecia incubated at higher temperatures (20 and $25^{\circ} \mathrm{C}$ ) matured rapidly, discharged large numbers of ascospores in the first 2 days, and then quickly senesced, whereas apothecia incubated at lower temperatures (10 and $15^{\circ} \mathrm{C}$ ) matured more slowly with a gradual increase in the numbers of ascospores produced (Fig. 4, Tables 1 and 2). This was more apparent in 2003, when the experiment was continued for 14 days. The total quantity of ascospores discharged in apothecia incubated at 10 and $15^{\circ} \mathrm{C}$ was similar to or greater than in apothecia incubated at 20 and $25^{\circ} \mathrm{C}$, because they persisted longer (Fig. 4, Tables 1 and 2). Apothecia survived longest at the lowest temperature $\left(10^{\circ} \mathrm{C}\right)$. In all cases, bacterial growth was observed on the surface of the apothecia as they senesced.

Effect of freezing on ascospore discharge and viability. In all treatments, the number of ascospores discharged after freezing was significantly reduced $(P \leq$ 0.004) compared with before the freezing treatment of the same apothecia. In the -2 , -4 , and $-6^{\circ} \mathrm{C}$ treatments, however, the number of ascospores discharged rebounded 2 days after freezing, and at this time were not significantly different from the numbers discharged before freezing (Fig. 5; $P=0.473$ ). The number of ascospores discharged in the $-8^{\circ} \mathrm{C}$ treatment did not rebound and remained low 2 days after freezing (Fig. 5; $P=0.772$ ).

There was a significant difference in germination of ascospores obtained from apothecia incubated at $-4,-6$, and $-8^{\circ} \mathrm{C}$ for $1 \mathrm{~h}$ compared with germination of ascospores incubated at $15^{\circ} \mathrm{C}(P \leq 0.05)$. There was no significant reduction in germination of ascospores from apothecia exposed to $-2^{\circ} \mathrm{C}$ compared with those incubated at $15^{\circ} \mathrm{C}(P \leq 0.05)$. On average, $50 \%$ of ascospores discharged from apothecia after incubation at $15^{\circ} \mathrm{C}$ or after freezing at $-2^{\circ} \mathrm{C}$ for $1 \mathrm{~h}$ germinated. After freezing at $-4^{\circ} \mathrm{C}$, ascospore germination was reduced to $25 \%$, at $-6^{\circ} \mathrm{C}$ to $12 \%$, and at $-8^{\circ} \mathrm{C}$ to $10 \%$ (Fig. 6 ).

\section{DISCUSSION}

In the present study, we document the stages of development of apothecia in relation to their ability to discharge ascospores. Although previous studies have investigated the biology of $M$. vacciniicorymbosi on blueberry, these studies focused mainly on the development of pseudosclerotia and/or the infection of host tissues by ascospores and conidia $(1,13)$. Our microscopic observations showed that even immature apothecia with cup openings of only $1 \mathrm{~mm}$ diameter contained some mature asci with fully formed asco- spores, which correlated well with the observation that apothecia with a cup opening as small as $1.2 \mathrm{~mm}$ were able to discharge ascospores. However, in general, apothecia did not start to discharge large numbers of ascospores ( $>100,000$ per day) until the cup opening was at least 3 to 4 $\mathrm{mm}$ diameter, at which stage microscopic observations showed that the hymenium consisted mostly of mature asci. These data suggest that while scouting blueberry fields for apothecia in the spring, it may be beneficial to make a note of how many of the apothecia observed have cups with an opening of at least $4 \mathrm{~mm}$ in diameter. If a large percentage of apothecia have cup openings $4 \mathrm{~mm}$ or greater, infection is likely to occur if susceptible leaf tissue is available and environmental requirements for infection are met. Thus, measures should probably be taken, such as the application of protective fungicide sprays, to protect susceptible blueberry foliage from infection. Such a technique may be less time-consuming than the use of spore traps $(16,17)$ in determining inoculum levels in the field. Since apothecia appear over an extended period in the spring (16), continued monitoring for apothecia is desirable.

In $M$. vaccinii-corymbosi, apothecia incubated at the higher temperatures (20 and $25^{\circ} \mathrm{C}$ ) discharged larger numbers of ascospores during the first 3 days of incubation than those incubated at lower temperatures $\left(10\right.$ and $\left.15^{\circ} \mathrm{C}\right)$. However, apothecia of $M$. vaccinii-corymbosi incubated at lower temperatures survived longer and produced cumulatively more ascospores over their
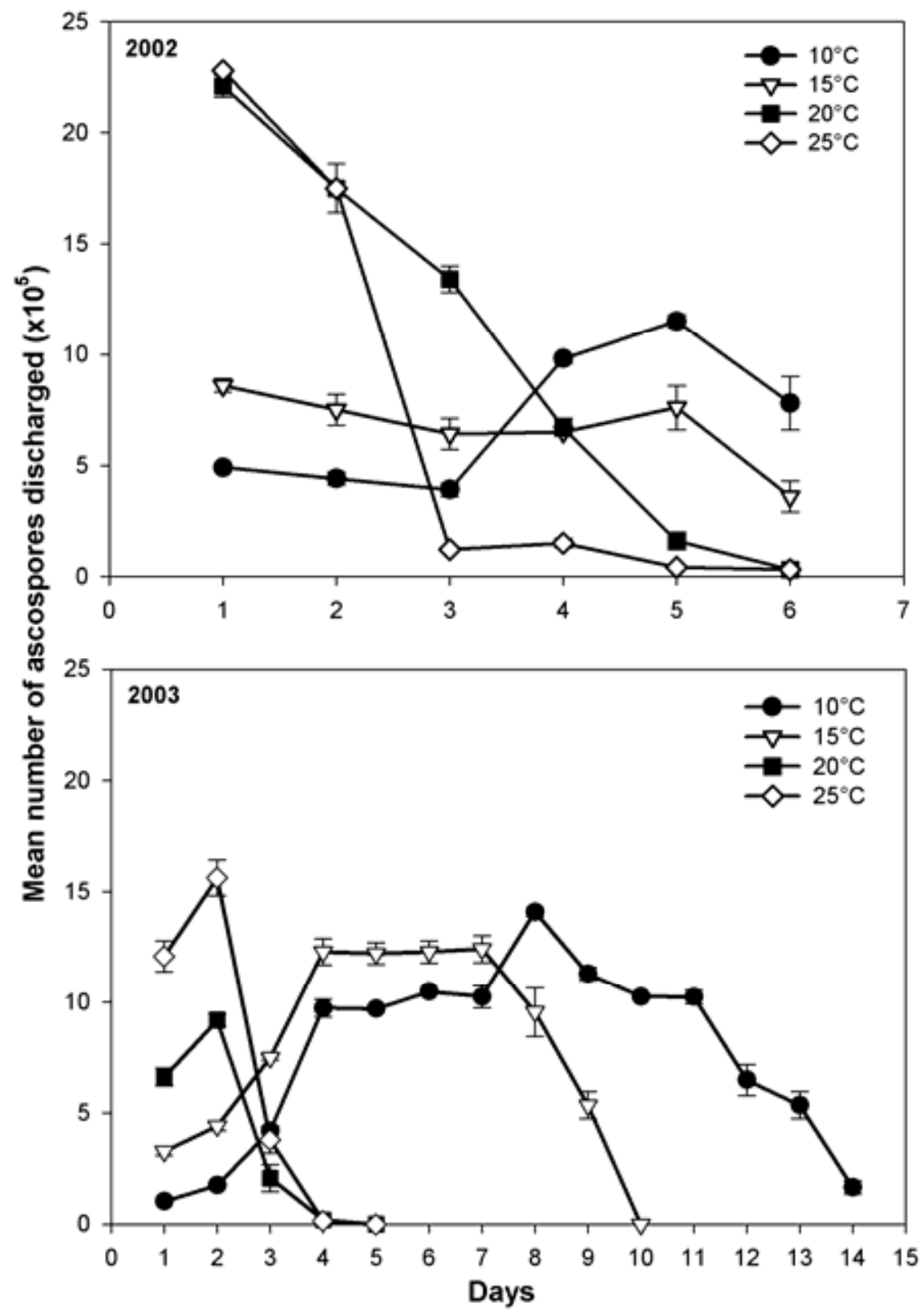

Fig. 4. Mean number of ascospores discharged per day by fully formed apothecia of Monilinia vaccinii-corymbosi at four constant temperatures of $10,15,20$, and $25^{\circ} \mathrm{C}$, in 2002 and 2003 . Each value represents the average of three replicates of at least 12 apothecia in 2002 and 6 apothecia in 2003. Vertical bars represent standard error of the mean for each value. 
lifetime than those incubated at 20 and $25^{\circ} \mathrm{C}$. Hong and Michailides (8) reported that the optimal temperature for ascospore discharge in $M$. fructicola was 15 to $16^{\circ} \mathrm{C}$. Their results also showed that apothecia incubated at $25^{\circ} \mathrm{C}$ discharged most of their ascospores within the first $24 \mathrm{~h}$ of incubation followed by a gradual decrease in the numbers of ascospores discharged as the incubation progressed. Apothecia of $M$. fructicola incubated at 10 and $15^{\circ} \mathrm{C}$ discharged lower numbers of ascospores but remained viable for a longer period of time. These results are similar to those observed in M. vaccinii-corymbosi. Previous studies indicated that the optimal temperature for ascospore germination in $M$. vaccinii-corymbosi was $15^{\circ} \mathrm{C}$ (15). Thus, not only are apothecia growing at lower temperatures likely to produce more ascospores over their lifetime, those ascospores are more likely to germinate and cause infection if they land on susceptible host tissues.

Apothecia of $M$. vaccinii-corymbosi survived longer and overall were most productive at $10^{\circ} \mathrm{C}$. This suggests that the fungus is well adapted to northern climates, and that during cool periods in the spring, inoculum availability may be prolonged. On the other hand, after several days with average temperatures of $20^{\circ} \mathrm{C}$ or above, inoculum levels may be expected to drop due to premature senescence of the apothecia. In addition to temperature, other factors such as moisture and hyperparasitism may affect longevity of apothecia. Thus, estimates of apothecial longevity based on temperature should take these factors into account.

Field observations in spring 2002 indicated that apothecia of $M$. vacciniicorymbosi were physically damaged by freezing temperatures. In the present study, apothecia experienced a significant drop in ascospore discharge after freezing for $1 \mathrm{~h}$. However, results showed that they were not permanently damaged by freezing for 1 $\mathrm{h}$ at temperatures down to $-6^{\circ} \mathrm{C}$ and were able to recover so that by 2 days after the freezing treatment there were no significant differences in ascospore production compared with the numbers of ascospores discharged in the $24 \mathrm{~h}$ before freezing. Apothecia frozen down to $-8^{\circ} \mathrm{C}$ were not able to recover their ability to discharge ascospores. It should be noted, however, that a control set of apothecia that were not frozen for the duration of the experiment was not included in the experiment. Therefore, it is not possible to rule out the involvement of extraneous factors in the observed decline in ascospore discharge and subsequent recovery. However, ascospore discharge by apothecia with 8- to 10- $\mathrm{mm}$ cups kept at nonfreezing temperatures in other experiments remained more or less constant for at least 3 to 4 days (Fig. 4). A large, sudden drop in ascospore discharge followed by an increase was never observed in the absence of freezing. While histological observations on frozen apothecia did not reveal obvious damage (P. S. Wharton and A. M. C. Schilder, unpublished data), it is possible that fully mature asci are more susceptible to freezing damage than less mature asci and lose their ability to discharge ascospores as a result of freezing. Less mature asci may then take $24 \mathrm{~h}$ to mature before starting to release ascospores. This may explain why the apparent recovery of the apothecia did not occur until 2 days after freezing. How-

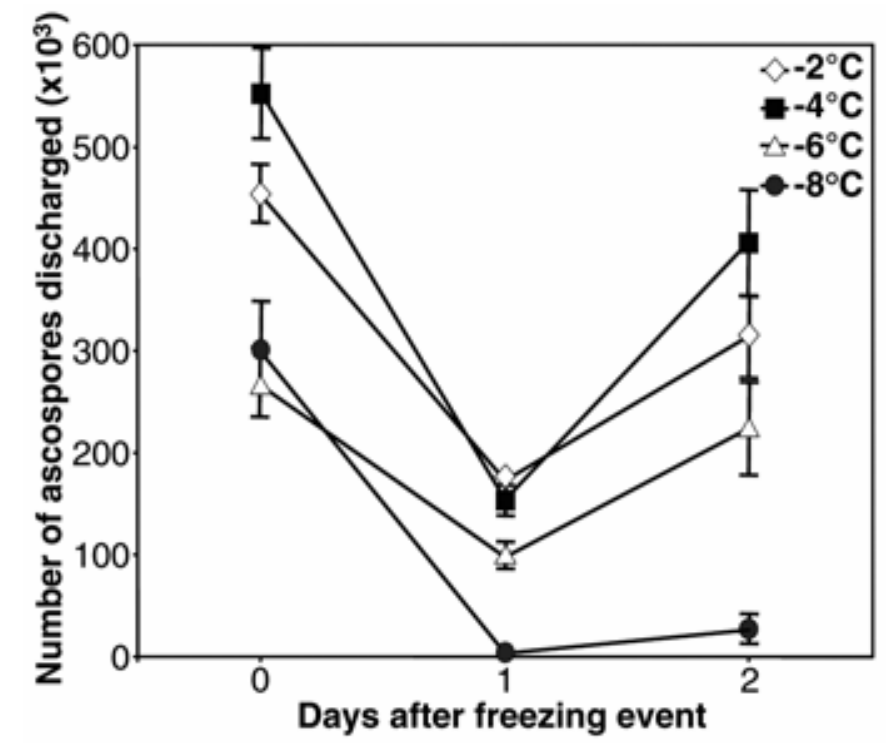

Fig. 5. Effect of freezing for $1 \mathrm{~h}$ at $-2,-4,-6$, and $-8^{\circ} \mathrm{C}$ on daily ascospore discharge by fully formed apothecia of Monilinia vaccinii-corymbosi. Values on day 0 represent the number of ascospores discharged by apothecia in the 24-h period (incubation at $15^{\circ} \mathrm{C}$ ) before freezing. Values on days 1 and 2 represent the daily number of ascospores discharged by the same apothecia 1 and 2 days after freezing treatments. Each value represents the average of two experiments with two replicates of at least six apothecia each per temperature treatment. Vertical bars represent standard error of the mean.

Table 1. Effect of temperature on ascospore discharge by apothecia of Monilinia vaccinii-corymbosi in $2002^{y}$

\begin{tabular}{lccc}
\hline & & Incubation temperature $\left({ }^{\circ} \mathbf{C}\right)$ \\
\cline { 2 - 4 } Variable & $\mathbf{1 0}$ & $\mathbf{1 5}$ & $\mathbf{2 0}$ \\
\hline Maximum daily discharge $\left(\times 10^{5}\right.$ ascospores per apothecium per day $)$ & $11.5 \mathrm{a}$ & $\mathbf{2 5}$ & $22.1 \mathrm{~b}$ \\
Total number of ascospores discharged $\left(\times 10^{6}\right.$ ascospores per apothecium $)$ & $42.3 \mathrm{a}$ & $22.8 \mathrm{~b}$ \\
Days to 95\% of total cumulative discharge ${ }^{\mathrm{z}}$ & 6 & $40.2 \mathrm{a}$ & $61.5 \mathrm{~b}$ \\
\hline
\end{tabular}

${ }^{y}$ Data were analyzed using Proc Mixed and the repeated measures design in SAS. Each value is the mean of three replicates of at least 12 apothecia each. Numbers followed by the same letter within a row did not differ significantly according to the least squares means test at $P \leq 0.05$.

${ }^{\mathrm{z}}$ The experiment was terminated after 7 days.

Table 2. Effect of temperature on ascospore discharge by apothecia of Monilinia vaccinii-corymbosi in $2003^{y}$

\begin{tabular}{|c|c|c|c|c|}
\hline \multirow[b]{2}{*}{ Variable } & \multicolumn{4}{|c|}{ Incubation temperature $\left({ }^{\circ} \mathrm{C}\right)$} \\
\hline & 10 & 15 & 20 & 25 \\
\hline Maximum daily discharge $\left(\times 10^{5}\right.$ ascospores per apothecium per day $)$ & $14.1 \mathrm{ab}$ & $12.4 \mathrm{ab}$ & $9.2 \mathrm{~b}$ & $15.6 \mathrm{a}$ \\
\hline Total number of ascospores discharged ( $\times 10^{5}$ ascospores per apothecium) & $106.5 \mathrm{a}$ & $79.2 \mathrm{~b}$ & $18.1 \mathrm{c}$ & $31.6 \mathrm{c}$ \\
\hline Days to $95 \%$ of total cumulative discharge ${ }^{z}$ & 13 & 8 & 2 & 2 \\
\hline
\end{tabular}




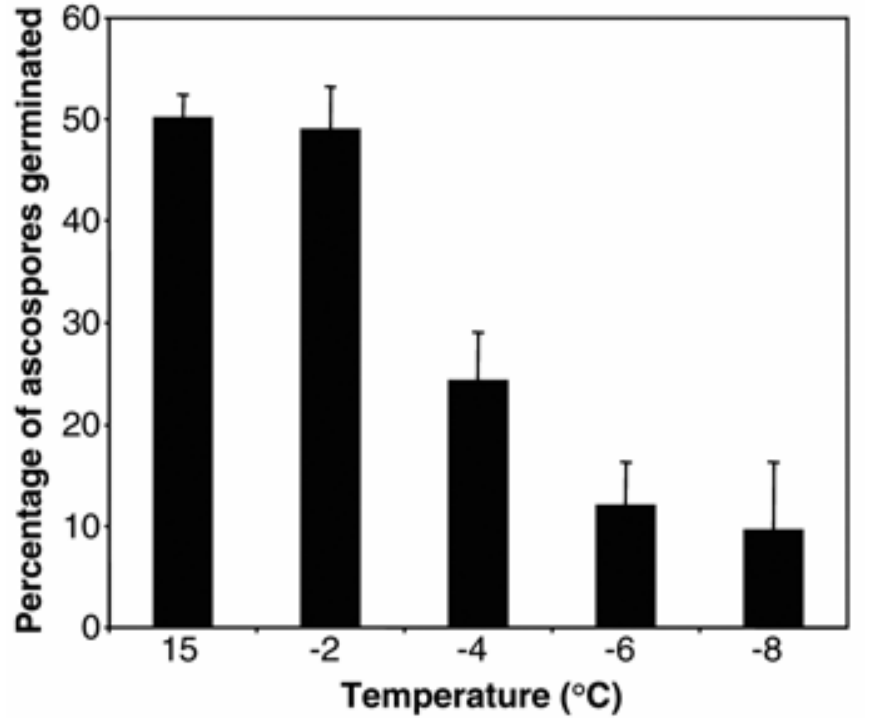

Fig. 6. Effect of freezing for $1 \mathrm{~h}$ at $-2,-4,-6$, and $-8^{\circ} \mathrm{C}$ on the viability of ascospores discharged by fully formed apothecia of Monilinia vaccinii-corymbosi. Each value represents the average of two experiments with two replicates of at least six apothecia each per temperature treatment. Vertical bars represent standard error of the mean.

ever, exposures of more than $1 \mathrm{~h}$ to freezing temperatures might have a more detrimental effect on apothecial functioning.

Freezing susceptibility of apothecia is of interest because a review of daily weather data (12) for southwest Michigan (Grand Junction) for the period from 1 April to 31 May for the past 3 years shows that the minimum air temperature has fallen below $-6^{\circ} \mathrm{C}$ on only four occasions. These temperatures occurred in the $3 \mathrm{~h}$ just before dawn and never lasted for more than $2 \mathrm{~h}$. Thus, apothecia of $M$. vaccinii-corymbosi appear well adapted to survive most freezing temperatures that occur in the spring in southwestern Michigan. However, it has been suggested that it may not be adaptation to low temperature per se that influences fungal survival in low-temperature environments, but rather adaptation to freeze-thaw cycles or desiccation (18). Therefore, the number of freezing events as well as conditions that promote desiccation may be more important factors in apothecial survival than a single freezing event, especially where apothecia are out in the open and not protected by a layer of leaf litter or other ground cover.

Although apothecia appear to be able to recover their ability to discharge ascospores after exposure to freezing temperatures, freezing did affect the viability of discharged ascospores. In the majority of freezing events in southwestern Michigan between 1 April and 31 May in 2001 to 2003, the temperature did not drop below $-2^{\circ} \mathrm{C}$. This may be significant because according to our results, apothecia and ascospores of $M$. vaccinii-corymbosi can survive such temperatures. However, pre- vious studies on lowbush blueberry ( $V$. angustifolium) have shown that vegetative buds are susceptible to freezing damage at $-2^{\circ} \mathrm{C}$ and that freezing down to $-2^{\circ} \mathrm{C}$ significantly increases the susceptibility of these tissues to infection by $M$. vacciniicorymbosi (6). If the same is true for highbush blueberry, it may therefore be important to apply protective fungicide sprays as soon as possible after a freezing event.

Currently, mummy berry control in Michigan is achieved mainly by the use of fungicides to protect the developing foliage and flowers from infection. However, fungicide options are few, and repeated use of these fungicides may lead to development of fungicide resistance in $M$. vaccinii-corymbosi. The results of this study suggest that it may be possible to improve timing of fungicide applications, and potentially reduce the amount of fungicide used for control of mummy berry, based on knowledge of apothecial development and effects of temperature on apothecial survival and longevity.

\section{ACKNOWLEDGMENTS}

This work was partially funded by Project GREEEN (Generating Research and Extension to meet Economic and Environmental Needs) at Michigan State University, the Rackham Foundation, and the Michigan Blueberry Growers. We thank William Kirk for critical reading of the manuscript.

\section{LITERATURE CITED}

1. Batra, L. R. 1983. Monilinia vacciniicorymbosi (Sclerotiniaceae) - Its biology on blueberry and comparison with related species. Mycologia 75:131-152.

2. Bristow, P. R. 1979. Mummy berry disease: Mummy germination. Pages 163-169 in: Proc.
North Am. Blueberry Res. Workers Conf. 4th. Division of Continuing Education, University of Arkansas, Fayetteville.

3. Cline, W. O. 2003. Harvest Update. North Carolina Cooperative Extension Service. N.C. Blueberry News 8:1-2.

4. Copes, W. E., Scherm, H., and Ware, G. O. 2001. Sequential sampling to assess the incidence of infection by Monilinia vacciniicorymbosi in mechanically harvested rabbiteye blueberry fruit. Phytopathology 91:348-353.

5. Cox, K. D., and Scherm, H. 2001. Effect of desiccants and herbicides on germination of pseudosclerotia and development of apothecia of Monilinia vaccinii-corymbosi. Plant Dis. 85:436-441.

6. Hildebrand, P. D., and Braun, P. G. 1991. Factors affecting infection of lowbush blueberry by ascospores of Monilinia vacciniicorymbosi. Can. J. Plant Pathol. 13:232-240.

7. Hildebrand, P. D., Milholland, R. D., and Stretch, A. W. 1995. Mummy berry. Pages 1112 in: Compendium of Blueberry and Cranberry Diseases. F. L. Caruso and D. C. Ramsdell, eds. American Phytopathological Society, St. Paul, MN.

8. Hong, C. X., and Michailides, T. J. 1998 Effect of temperature on the discharge and germination of ascospores by apothecia of Monilinia fructicola. Plant Dis. 82:195-202.

9. Korf, R. P. 1958. Japanese Discomycetes Notes I-VIII. Sci. Rep. Yokohama Nat. Univ., Sect. II, No. 7, pp. 7-35.

10. Lehman, J. S., and Oudemans, P. V. 1997. Phenology of apothecium production in populations of Monilinia vaccinii-corymbosi from early- and late-maturing blueberry cultivars. Phytopathology 87:218-223.

11. Lehman, J. S., and Oudemans, P. V. 2000. Variation and heritability of phenology in the fungus Monilinia vaccinii-corymbosi on blueberry. Phytopathology 90:390-395.

12. Michigan Automated Weather Network, 2004. Michigan Climatological Resources Program, Michigan State University, East Lansing.

13. Milholland, R. D. 1977. Sclerotium germination and histopathology of Monilinia vacciniicorymbosi on highbush blueberry. Phytopathology 67:848-854

14. Ngugi, H. K., Scherm, H., and Lehman, J. S. 2002. Relationships between blueberry flower age, pollination, and conidial infection by Monilinia vaccinii-corymbosi. Phytopathology 92:1104-1109.

15. Ramsdell, D. C., Nelson, J. W., and Myers, R. L. 1974. An epidemiological study of mummy berry disease of highbush blueberry. Phytopathology 64:222-228.

16. Ramsdell, D. C., Nelson, J. W., and Myers, R. L. 1975. Mummy berry disease of highbush blueberry: epidemiology and control. Phytopathology 65:229-232.

17. Ramsdell, D. C., Nelson, J. W., and Myers, R. L. 1976. Interaction of eradicant and protectant treatments upon the epidemiology and control of mummy berry disease of highbush blueberry. Phytopathology 66:350-354.

18. Robinson, C. H. 2001. Cold adaptation in Arctic and Antarctic fungi. New Phytol. 151:341-353.

19. Scherm, H., and Copes, W. E. 1999. Evaluation of methods to detect fruit infected by Monilinia vaccinii-corymbosi in mechanically harvested rabbiteye blueberry. Plant Dis. 83:799-805.

20. Scherm, H., Savelle, A. T., and. Pusey, P. L. 2001. Interactions between chill-hours and degree-days affect carpogenic germination in Monilinia vaccinii-corymbosi. Phytopathology 91:77-83 